\title{
The Effect of Training on Work Motivation and Its Impact on Employee Performance (Case Study at BPJS Ketenagakerjaan Headquarters)
}

\author{
Mochammad Habibie \\ Magister Management \\ Perbanas Institute \\ Jakarta, Indonesia
}

\author{
Ika Mustika \\ Magister Management \\ Perbanas Institute \\ Jakarta, Indonesia
}

\begin{abstract}
This study aims to find out and analyze how the training provided affects work motivation and how it impacts on BPJS Ketenagakerjaan performance. The population of this study was all 4,445 employees of the BPJS Employment Office. The sample in this study, based on the Issac and Michael table with $5 \%$ apha, was 323 people (headquarters employees). Sample collection using simple random sampling. The analysis technique used in this study uses Structural Equation Modeling (SEM) with the LISREL 8.70 program. This study shows that (1) Training influences work motivation. (2) Motivation influences employee performance. (3) Training influences employee performance (4) Training and motivation together influence employee performance (5) Training has an indirect effect on employee performance through motivation as a mediating variable.
\end{abstract}

Keywords:- Training, work motivation, and employee performance.

\section{INTRODUCTION}

The human resource factor in an organization plays a significant role. Social resource factors can cause the failure of a business to achieve its goals in the organization. A large company is aware of the need to increase its competitive advantage from accessible resources. Human resources in an organization is a series of added value for the company to achieve its goals. Therefore human resources owned need to work efficiently and effectively to improve company performance.

Workers or personnel use their skills and knowledge to offer assistance to organizations on how to achieve goals. Organizations must be able to ensure that employees have sufficient knowledge and are motivated to perform better company performance (Geelmalee, 2019). Training is needed to ensure that resources can work efficiently and technically and socially competent for department and management positions (Mullins, 2007). Training and human resource development affect employee motivation at work (Simmamora, 1997).

Every organization cannot improve performance from one or two people's efforts, but instead, there must be an effort from the whole organization members. Companies must pay attention to how to build and motivate employees to work more effectively and responsibly so that the goals set by the company previously achieved (Siagian, 2009).

Training is essential for companies that want to advance to anticipate technological progress. With the training expected to improve employees' skills and expertise, skills, and expertise are needed in every activity of the company (Hasibuan, 2000). Training is the main target that must be pursued by the company in improving the performance of its employees so that within them arises a high enthusiasm and motivation in every implementation of their work activities.

BPJS Ketenagakerjaan is an organizing body tasked with organizing national labor guarantees, with a vision to become a Social Security Organizing Board that is proud of the nation, is well-governed, and excels in operations and services. In achieving its vision, it should have highly motivated employees, perform well in doing their jobs, and work effectively and efficiently. To then be able to provide high employee performance to realize the company's mission and goals.

Based on the description above and conceptual framework, in this study, the researchers aimed to find out: (1) Training influences work motivation. (2) Motivation influences employee performance. (3) Training influences employee performance (4) Training and motivation together influence employee performance (5) Training has an indirect effect on employee performance through motivation as a mediating variable.

\section{LITERATURE REVIEW}

\section{A. Training}

Training is a short-term educational process that uses systematic and organized procedures where non-managerial employees learn technical knowledge and skills in limited goals (Sikula, 2011). Training as a process teaches the skills needed by new employees to do their jobs (Dessler, 2004). Training is a tool that is shown to activate further the work of less active members of the organization before, reducing negative impacts due to lack of education, limited experience, or lack of confidence from individual members or groups of members (Sedarmayanti, 2013). Training is the process of teaching new or existing employees the necessary skills they need to carry out their work (Dessler, 2009). 
Training is one of the efforts to improve the quality of human resources in the world of work.

Job training is intended to get workers who have the knowledge, excellent skills, abilities, and good attitudes to fill available job positions with high work productivity, which can produce exceptional work results (Siagian, 2004). Job training indicators include:

Knowledge is the process of life that humans know directly from their consciousness.

$>$ Thinking ability is a reflective, critical, and creative reasoning activity oriented to an intellectual process that involves conceptualizing, applying, analyzing, evaluating information collected (synthesis), or produced through observation, experience, reflection, and communication as a foundation for beliefs and actions.

$>$ Attitude is an evaluative statement, both pleasant and unpleasant towards the object, individual, or event.

$>$ Skill is a skill that allows a person to get a job or to be able to keep working, including personal skills, interpersonal skills, attitudes, habits, and behaviors.

Onditi at all (2018) Influence of Employee Training Research in Organizational Performance: A Case Of Kenya's KISII County Government, which examines the effect of training on organizational performance. In this study, it was found that training had a positive impact on company performance.

Esha (2016) A Study of Effectiveness of Training \& Development Program in Bank Employees Performance, which examines the objective results of training and employee development. The results of this study found that there is an influence between training and employee development programs on company performance.

Muganga, (2018) Research Training, employee engagement, and employee performance: Evidence from Uganda's health sector, the results of the study found a relationship between employee training and performance in the health sector in Uganda. This research was conducted on four Catholic hospitals in Uganda.

\section{B. Work Motivation}

Motivation is defined as the whole process of giving encouragement/stimulation to employees so that they are willing to work willingly without being forced (Saydam, 2000). On a company scale, individual motivation can be an impetus to achieve the company's goals and himself (Robbins, 2001). Motivation usually arises because of an insatiable need or a need that has not been met.

Indicators to measure work motivation (Syahyuti, 2010), namely:

\section{$>$ The drive to reach the goal:}

Someone who has a high work motivation then in him has a strong drive to achieve maximum performance, which in turn will affect the purposes of a company or agency.
$>$ Work spirit:

The spirit of work as an excellent psychological state if morale creates an excitement that encourages someone to work harder and better and is consistent in achieving the goals set by the company or agency.

\section{$>$ Initiative and creativity :}

The effort is defined as the strength or ability of an employee or employee to start or continue a job with full energy without any encouragement from others or of his own will. At the same time, creativity is the ability of an employee or employee to find new relationships and make combinations that are new so they can find something new.

\section{$>$ A sense of responsibility:}

The attitude of individual employees who have the right work motivation must have a sense of responsibility towards the work they do so that the work can be completed promptly.

Geelmalee (2019) Research on the Impact of Employee Motivation on Organizational Performance examines the influence of motivation on performance. This study found that motivation influences organizational performance. Well motivated employees produce good outcomes that affect organizational performance.

Dantes (2017) Research The Effect Of Leadership, Work Motivation, Work Environment Toward Employees Perform, found that work motivation affects employee performance. This study also explains research results that affect performance in addition to work motivation and leadership and work environment.

Ali (2016) Research on The Impact of Motivation on the Employee Performance and Job Satisfaction in IT Park (Software House) Sector of Peshawar, Pakistan. This study explains the importance of motivation for employee performance. Research in the IT Park industry sector found that motivation influences employee performance in Pakistan.

\section{Employee Performance}

Employee performance (work performance) is the quality and quantity of work achieved by an employee in carrying out duties following the responsibilities given to him (Mangkunegara, 2012).

Indicators to measure performance (Boediharjo, 2002), namely:

Effectiveness and efficiency, namely the ability to get the job done correctly, the ability to choose the right equipment to achieve the goal.

$>$ The orientation of responsibility, namely the ability to complete the work with full responsibility and evaluate the job correctly.

$>$ Discipline is the attitude or ability to complete work promptly and following specified targets.

$>$ The initiative, namely the ability to ask questions, give criticisms and suggestions. 


\section{Framework}

Human resources in a company are one of the internal resources for companies in achieving organizational goals. Great company performance can be achieved through human resources who can work effectively and efficiently following outputs that follow those set by the company. Training is one way to improve work skills and motivation for employees. High work knowledge and skills can affect employee motivation and performance. So that employee training is one of the objective ways to improve employee performance to achieve the goals set by the organization.

\section{E. Hypothesis}

H1:Training influences work motivation

> H2:Motivation influences Employee Performance

$>$ H3:Training influences employee performance

$>$ H4:Training and Motivation jointly influence Employee Performance

$>$ H5:Training has an indirect effect on Employee Performance through Motivation as a Mediation variable

\section{RESEARCH METHODOLOGY}

This study uses descriptive analysis to determine the characteristics of respondents' responses to the question items on the questionnaire and inferential analysis using the SEM method with the Lisrel 8.70 program. This research population is 4,445 employees of BPJS Employment, so the sample used is based on the Issac, and Michael table with $5 \%$ apha is 323 people. The research approach used is quantitative; the type of research is a survey with descriptive-analytical methods where data is collected through questionnaires. Questionnaire items were measured using 5 Likert scales ranging from 1 "strongly disagree" to 5 "strongly agree."

The data analysis tool used in this study to test the hypothesis is a full model using the Structural Equation Model (SEM) operated through the Lisrel 8.70 program. Based on the full model obtained by the Standardized model and the T-Value model, with the results of processing in figure 1 and figure 2 . While the results of the conformity test of the Goodness of Fit Index model can be seen in Table 1 as follows:

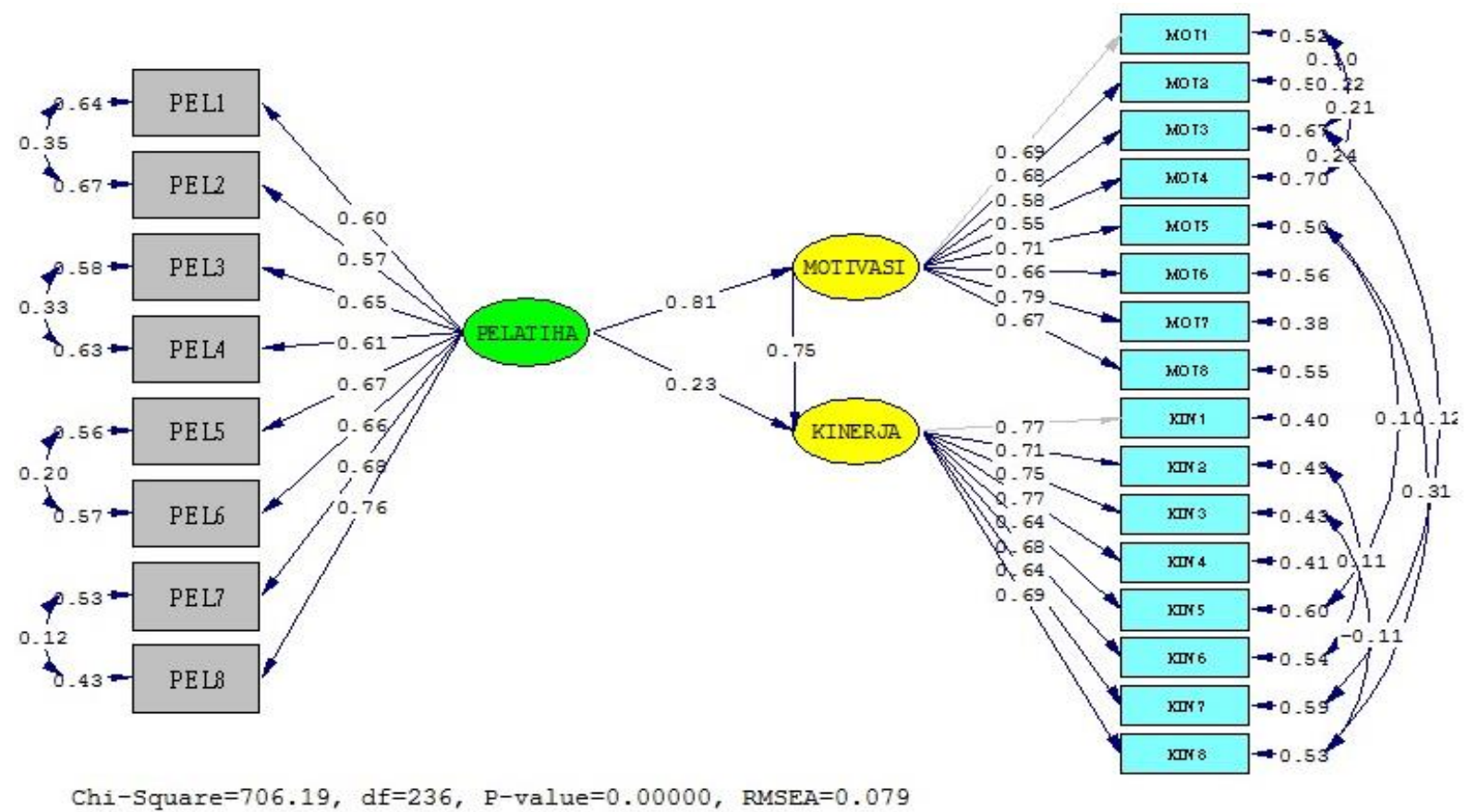

Fig 1:- Hypothesis Model based on Standardized Values 


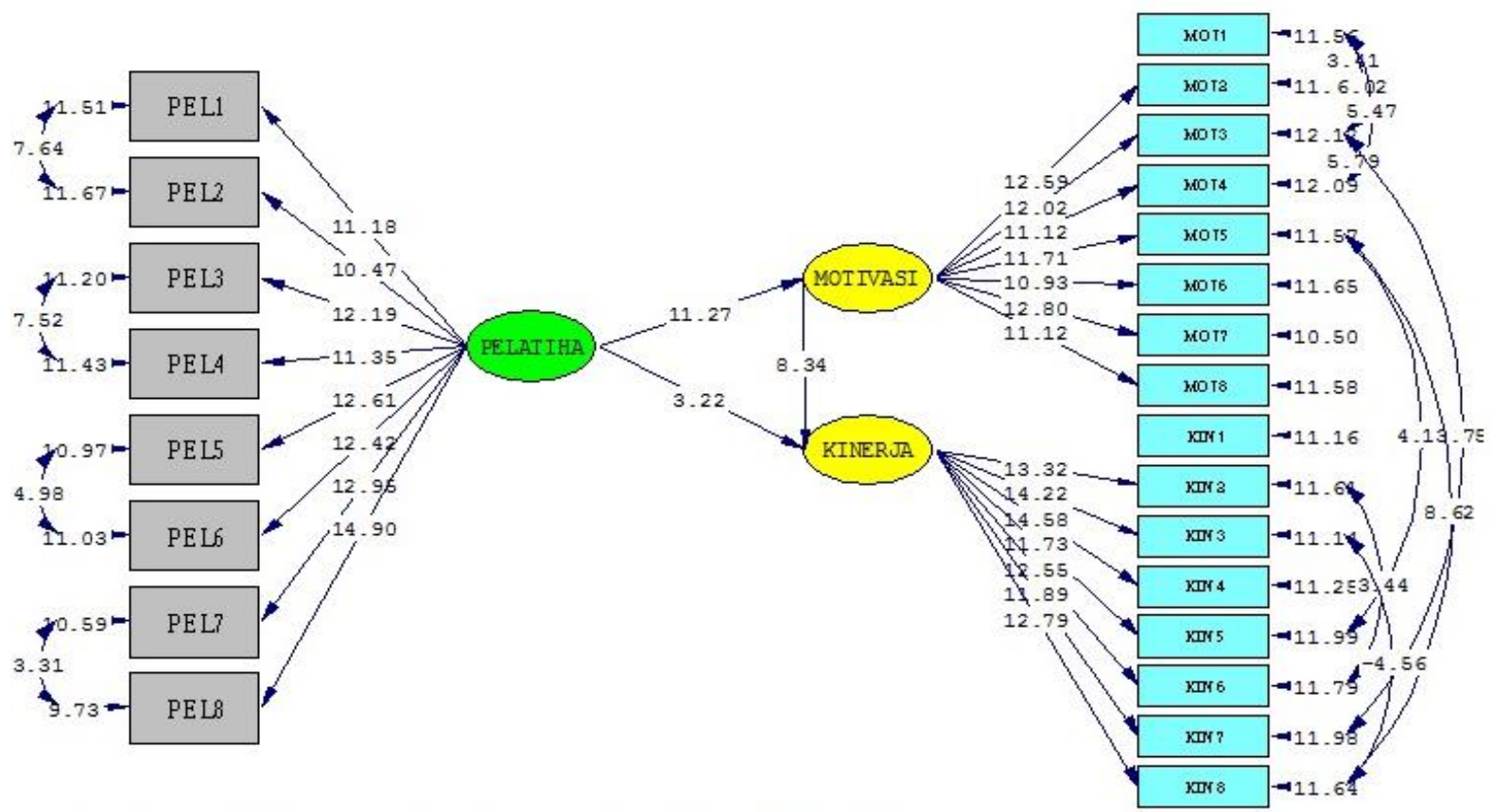

Chi-Square $=706.19, d f=236, P-$ value $=0.00000, \quad$ RMSEA $=0.079$

Fig 2:- Hypothesis Model based on T-Value

\begin{tabular}{|c|c|c|c|}
\hline \multicolumn{1}{|c|}{ Expected size } & Estimated Results & Conclusion \\
\hline \multicolumn{2}{|c|}{ Absolute Fit Size } \\
\hline GFI & GFI $>0.9$ & 0.85 & Marginal Fit \\
\hline RMSEA & RMSEA $<0.08$ & 0.078 & Good fit \\
\hline NNFI & NNFI $>0.90$ & 0.97 & Good fit \\
\hline NFI & NFI $>0.90$ & 0.96 & Good fit \\
\hline AGFI & AGFI $>0.90$ & 0.80 & Marginal Fit \\
\hline RFI & RFI $>0.90$ & 0.95 & Good fit \\
\hline CFI & IFI $>0.90$ & 0.97 & Good fit \\
\hline
\end{tabular}

Table 1:- Size of model suitability

Based on table 1, it can be seen that there are six conformity measurements obtained that have a useful fit model index (Good Fit), while the only GFI and AGFI have a marginal fit model conformity index. So overall, the model is declared good and can be used for further analysis.

\begin{tabular}{|c|c|c|c|c|c|c|}
\hline \multicolumn{2}{|c|}{ Measurement model } & \multirow{2}{*}{$\begin{array}{c}\text { Factor weight } \\
\text { coefficient }\end{array}$} & \multirow{2}{*}{$\begin{array}{c}\text { T value } \\
\text { calculated }\end{array}$} & \multirow{2}{*}{ t-table } & \multirow{2}{*}{$\begin{array}{l}\text { Test results } \\
(t>1.96)\end{array}$} & \multirow{2}{*}{$\mathbf{R 2}$} \\
\hline Latent Variable & Dimension & & & & & \\
\hline \multirow{8}{*}{ Training } & PEL1 & 0.6 & 11.18 & 1.96 & Significant & 0.36 \\
\hline & PEL2 & 0.57 & 10.47 & 1.96 & Significant & 0.33 \\
\hline & PEL3 & 0.65 & 12.19 & 1.96 & Significant & 0.42 \\
\hline & PEL4 & 0.61 & 11.35 & 1.96 & Significant & 0.37 \\
\hline & PEL5 & 0.67 & 12.61 & 1.96 & Significant & 0.44 \\
\hline & PEL6 & 0.66 & 12.42 & 1.96 & Significant & 0.43 \\
\hline & PEL7 & 0.68 & 12.95 & 1.96 & Significant & 0.47 \\
\hline & PEL8 & 0.76 & 14.9 & 1.96 & Significant & 0.57 \\
\hline \multirow{3}{*}{ Motivation } & MOT1 & 0.69 & default & 1.96 & Significant & 0.48 \\
\hline & MOT2 & 0.68 & 12.59 & 1.96 & Significant & 0.47 \\
\hline & MOT3 & 0.58 & 12.02 & 1.96 & Significant & 0.33 \\
\hline
\end{tabular}


ISSN No:-2456-2165

\begin{tabular}{|c|c|c|c|c|c|c|}
\hline \multirow{5}{*}{} & MOT4 & 0.55 & 11.12 & 1.96 & Significant & 0.30 \\
\cline { 2 - 7 } & MOT5 & 0.71 & 11.71 & 1.96 & Significant & 0.50 \\
\cline { 2 - 7 } & MOT6 & 0.66 & 10.93 & 1.96 & Significant & 0.44 \\
\cline { 2 - 7 } & MOT7 & 0.79 & 12.8 & 1.96 & Significant & 0.62 \\
\cline { 2 - 7 } & MOT8 & 0.67 & 11.12 & 1.96 & Significant & 0.45 \\
\hline \multirow{5}{*}{ The performance } & KIN1 & 0.77 & default & 1.96 & Significant & 0.60 \\
\cline { 2 - 7 } & KIN2 & 0.71 & 13.32 & 1.96 & Significant & 0.51 \\
\cline { 2 - 7 } & KIN3 & 0.75 & 14.22 & 1.96 & Significant & 0.57 \\
\cline { 2 - 7 } & KIN4 & 0.77 & 14.58 & 1.96 & Significant & 0.59 \\
\cline { 2 - 7 } & KIN5 & 0.64 & 11.73 & 1.96 & Significant & 0.4 \\
\cline { 2 - 7 } & KIN6 & 0.68 & 12.55 & 1.96 & Significant & 0.46 \\
\cline { 2 - 7 } & KIN7 & 0.64 & 11.89 & 1.96 & Significant & 0.41 \\
\cline { 2 - 7 } & KIN8 & 0.69 & 12.79 & 1.96 & Significant & 0.47 \\
\hline
\end{tabular}

Table 2:- Structural measurement model

Source: Results of processing with Lisrel 8.70

Based on the results in table 2, it can be seen that:

Regression coefficient (factor weight) resulting from the latent variable of training on the dimensions of PEL1 to PEL8 is greater than 0.50 with a t value greater than 1.96 at a significance level of $5 \%$, it can be said that the dimensions of PEL1 to PEL8 are all declared valid and significant to be made indicators of training latent variables so that they will be used in further analysis.

The value of the regression coefficient (factor weight) resulting from the latent variable of motivation towards dimensions MOT1 to MOT8 is greater than 0.50 with a $t$ value greater than 1.96 at a significance level of $5 \%$. It can be said that the dimensions of MOT1 to MOT8 are all declared valid and significant to be made indicator of latent motivation so that it will be used in further analysis.

Regression coefficient (factor weight) resulting from the latent variable performance of the dimensions of KIN1 to KIN8 is more significant than 0.50 with a $\mathrm{t}$ value greater than 1.96 at a significance level of $5 \%$, it can be said that the dimensions of KIN1 through KIN8 are all declared valid and significant to be made indicator of latent performance variables so that it will be used in further analysis.
Based on the results in Figures 1 and 2, multiple regression equations can be arranged for the construct variables:

- Motivation = 0.81 Training (1)

- Performance $=0.75$ Motivation +0.23 Training (2)

Based on structural equation 1, it can be seen that the direct effect of training variables on motivation is $(0.81 \mathrm{x}$ $0.81)=0.6561$ or $65.61 \%$,

Based on structural equation 2, the magnitude of the direct effect of training variables on performance is $0.23 \times 0.23=0.0529$ or $5.29 \%$, while the magnitude of the direct influence of motivation variables on performance is $0.75 \times 0.75=0.5625$ or $56.25 \%$ and the magnitude of the direct effect of training on motivation is $0.81 \times 0.81=$ 0.6561 or $65.61 \%$. Furthermore, the effect of training and motivation variables together on performance is the remaining $89 \%$ by $11 \%$ influenced by other factors.

In detail the influence together (Full Mediating), Direct $(\mathrm{c})=0.23 \times 0.23=0.0529$. Indirect $\left(\mathrm{C}^{\prime}\right)=$ Pel-Mot-Kin $=$ $0.81 \times 0.75=0.6075$.

The value of the indirect effect at $C^{\prime}=0.6075$ turned out to be higher than the direct effect at $\mathrm{c}=0.0529$, indicating that motivation was a mediating variable of training and performance. This proves that hypothesis five is insulted; namely, training has an indirect effect on Employee Performance through Motivation as a Mediation variable. 
ISSN No:-2456-2165

\begin{tabular}{|c|c|c|c|c|c|c|}
\hline \multicolumn{2}{|c|}{ Measurement Equation } & \multirow[b]{2}{*}{$\begin{array}{l}\text { Path coefficient } \\
\text { (standardized) }\end{array}$} & \multirow[b]{2}{*}{$\begin{array}{c}\text { Standard Error } \\
\text { (SE) }\end{array}$} & \multirow[b]{2}{*}{ t count } & \multirow[b]{2}{*}{ t-table } & \multirow[b]{2}{*}{$\begin{array}{l}\text { Test results } \\
(t>1.96)\end{array}$} \\
\hline $\begin{array}{c}\text { Endogenous } \\
\text { latent variables }\end{array}$ & $\begin{array}{c}\text { Exogenous / } \\
\text { Endogenous } \\
\text { latent variables }\end{array}$ & & & & & \\
\hline $\begin{array}{l}\text { Motivation } \\
\text { (partial) }\end{array}$ & Training & 0.81 & 0.072 & 11.27 & 1.96 & H1 Significant \\
\hline \multirow{2}{*}{$\begin{array}{l}\text { Performance } \\
\text { (partial) }\end{array}$} & Motivation & 0.75 & 0.089 & 8.34 & 1.96 & H2 Significant \\
\hline & Training & 0.23 & 0.072 & 3.22 & 1.96 & H3 Significant \\
\hline $\begin{array}{c}\text { Endogenous } \\
\text { latent variables }\end{array}$ & $\begin{array}{c}\text { Exogenous } \\
\text { latent variables }\end{array}$ & $\begin{array}{c}\text { Coefficient of } \\
\text { Determination (R2) }\end{array}$ & Impact Weight & F count & f-table & Test results \\
\hline $\begin{array}{c}\text { Performance } \\
\text { (Simultaneous) }\end{array}$ & PEL + MOT & 0.89 & $\begin{array}{c}\mathrm{R}=\sqrt{\mathrm{R} 2}= \\
\sqrt{ }(0.89)=0.94\end{array}$ & 1294.55 & 3.02 & H4 Significant \\
\hline Information : & & & & & & \\
\hline \multicolumn{4}{|c|}{$\mathrm{f}$-table $=3.02$ at $\mathrm{a}=5 \%$ and free degrees $\mathrm{db} 1=\mathrm{k}=2$ and $\mathrm{db} 2=\mathrm{nk}-1=323-2-1=320$} & & & \\
\hline \multicolumn{4}{|c|}{$\mathrm{t}$-table $=1.97$ at $\mathrm{a}=5 \%$ with 2 -sided test and free degrees $\mathrm{db}=\mathrm{nk}-1=323-2-1=320$} & & & \\
\hline f- arith & & & & & & \\
\hline
\end{tabular}

Table 3:- Hypothesis Testing Test

In this study, there were five hypotheses tested, from the five hypotheses based on the test results in table 3 , it was concluded that all hypotheses were proven to be significant and significant on performance. The table above concludes that hypotheses $\mathrm{H} 1, \mathrm{H} 2, \mathrm{H} 3, \mathrm{H} 4$, and $\mathrm{H} 5$ are proven to influence performance, both partially and simultaneously (together), and motivation can be proven to be a mediating variable, where training has an indirect effect on Employee Performance through Motivation as a Mediation variable.

Italicize Roman symbols for quantities and variables, but not Greek symbols. Use a long dash rather than a hyphen for a minus sign. Punctuate equations with commas or periods when they are part of a sentence.

\section{CONCLUSION}

The conclusions of this study are as follows: One, training has a significant and positive effect on performance, meaning that the better the training, the better the performance of employees. Second, motivation has a positive and significant impact on performance, meaning that the better the motivation employee's motivation, the better the performance of the employee. Third, training has a substantial and positive effect on motivation, meaning that the better the training, the better the motivation that employees will have. Fourth, training and motivation together have a significant and positive effect on performance, meaning that the better the training and motivation are carried out simultaneously, the better the performance provided by employees. And finally, motivation is proven to be a mediating variable; that is, training has an indirect effect on Employee Performance through Motivation as a Mediation variable.

\section{REFERENCES}

[1]. A.A Anwar Prabu Mangkunegara. 2012. Evaluasi Kinerja Sumber Daya Manusia.Bandung: PT. Refika Aditama.

[2]. Ali, Zulfikar, Huang Zian Piang, Li Zhong Bin, Amjad Ali (2016) Penelitian The Impact of Motivation on the Employee Performance and Job Satisfaction in IT Park (Software House) Sector of Peshawar, Pakistan. International Journal of Academic Research in Business and Social Sciences 2016, Vol. 6, No. 9.

[3]. Andrew E. Sikula. 2011. Manajemen Sumber Daya Manusia, Erlangga. Bandung.

[4]. Boediharjo. 2002. Kinerja Organisasi. Erlangga: Jakarta.

[5]. Dantes, Reisza Valewey, Jefrey Ignatius (2017) Penelitian The Effect Of Leadership, Work Motivation, Work Environment Toward Employees Perform. International Journal of Advance Research (IJAR).

[6]. Dessler, Gary, 2004. Manajemen Sumber Daya Manusia, Edisi 9.Volume 1. Jakarta : Kelompok Gramedia

[7]. , 2009, Manajemen Sumber Daya Manusia, Edisi Kesepuluh, Volume II, Indeks, Jakarta.

[8]. Esha (2016) Research A Study of Effectiveness of Training \& Development Programmeon Bank Employees Performance.

[9]. Geelmaale, Abdi Muse Ali, 2019. Impact Of Employee Motivation On Organizational Performance. International Journal of Advance Research (IJAR).

[10]. Gaouzali, Saydam. 2000. Manajemen Sumber Daya Manusia (Suatu Pendekatan Mikro). Jakarta: Djambatan. 
[11]. Hasibuan, Malayu,SP (2000), Manajemen Sumber daya Manusia, Penerbit Bumi Aksara, Jakarta.

[12]. Mullins, J. Laurie. (2007). Management and organizational Behavior 8th ed. Prentice Hall. Pearson Education, Edinburg Gate.

[13]. Kasimu Sendawula, Saadat Nakyejwe Kimuli, Juma Bananuka \& Grace Najjemba Muganga | (2018) Training, employee engagement and employee performance:Evidence from Uganda's health sector, Cogent Business \& Management, 5:1, 1470891

[14]. Onditi, Arvinlucy, Maria Oryango, Joash Omosha at all (2018) Penelitian Influence of Employee Training On Organization Performance : A Case Of KISII County Government Kenya. International Journal of Advance Research (IJAR).

[15]. Robbins, P. Stephen. (2001). Perilaku Organisasi. Volume 1. Eighth Edition. Translated by : Dr. Hadyana Pujaatmaka. Erlangga, Jakarta.

[16]. Sedarmayanti. 2011. Tata Kerja dan Produktivitas Kerja :Suatu Tinjauan Dari Aspek Ergonomi Atau Kaitan Antara Manusia Dengan Lingkungan Kerjanya. Third Matter. Bandung: Mandar Maju

[17]. Siagian, BP. 2004. Manajemen Sumber Daya Manusia, Jakarta. Bumi. Aksara.

[18]. Simamora, Henry. (1997).Manajemen Sumber Daya Manusia Edition to 2. Yogyakarta : STIE YKPN

[19]. Syahyuti. (2010). Definisi, Variabel, Indikator dan Pengukuran dalam Ilmu Sosial. [Online]. Accessed from : http://syahyutivariabel.blogspot.com 